\title{
CONTRIBUTION OF ENVIRONMENTAL FACTORS TOWARD DISTRIBUTION OF TEN MOST DANGEROUS WEED SPECIES GLOBALLY
}

\author{
WAN, J.-Z. ${ }^{1}-$ WANG, C.-J. ${ }^{1,2^{*}}$ \\ ${ }^{1}$ State Key Laboratory of Plateau Ecology and Agriculture, Qinghai University, Xining 810016, \\ China \\ ${ }^{2}$ College of Agriculture and Animal Husbandry, Qinghai University, Xining 810016, China \\ *Corresponding author \\ e-mail: wangchunjing00@163.com \\ (Received 14 ${ }^{\text {th }}$ Jun 2019; accepted $25^{\text {th }}$ Oct 2019)
}

\begin{abstract}
Weeds can be a global threat to biodiversity and ecosystems. Understanding the contribution of environmental factors toward weed distribution can vastly improve the effectiveness of the methods adopted for the prevention and control of weed expansion on a large scale. Through multiple studies, we are now aware of the top 10 most dangerous weed species (in terms of endangering biodiversity). However, few studies have paid attention to the contribution of environmental factors toward the distribution of these weed species globally. In this study, we used species distribution modelling to project weed distribution based on occurrence records and environmental factors. We then used the jackknife estimation to assess the contribution of environmental factors toward weed distribution globally. Our results showed that climatic factors coupled with the human ecological footprint significantly contributed toward the distribution of these weed species. However, annual mean temperature made the largest contribution toward the distribution, except in the case of Sorghum halepense. Concerning distribution, different weed species respond differently to the annual mean temperature. However, the human ecological footprint can enhance their global distribution. We suggest that climate change and human influence should be analyzed together to realize methods for the prevention and control of the 10 most dangerous weed species globally.
\end{abstract}

Keywords: climatic factor, human ecological footprint, risk monitoring, soil, species distribution modelling, weed management, worldwide

\section{Introduction}

Weeds have a high potential to threaten biodiversity and ecosystem functions around the world (Holm, 1969; Tilman et al., 2006; Bajwa et al., 2016; Krak et al., 2019). Owing to their generally broad physiological niches and/or specific traits, weeds can invade human-mediated ecosystems with relative ease (Holm, 1969; Tilman et al., 2006; Shimono and Konuma, 2008; Panetta, 2015). Weed expansion can affect biodiversity across different spatial scales; for example, they can spread widely in disturbed or degraded environments (Shimono and Konuma, 2008). Thus, weed species could be dominant in such habitats and deplete the resources available to native plants, resulting in decreased biodiversity (Holm, 1969; Tilman et al., 2006; Shimono and Konuma, 2008). Furthermore, weed invasion could significantly decrease the ecosystem functions (e.g., nutrient cycling and biomass productivity) (Tilman et al., 2006; Bajwa et al., 2016; Zhang et al., 2018). Such negative effects on biodiversity and ecosystem functions may be due to the wide distribution of weeds as well as the spatial changes observed in environmental factors (Holm, 1969; Tilman et al., 2006; Shimono and Konuma, 2008; Panetta, 2015; Zhang et al., 2018). 
Holm (1969) listed the 10 most dangerous weed species globally. These species have large distribution ranges and can expand widely across different environmental conditions. Ervin and Holly (2011) used species distribution modelling (SDM) to project the distribution of Imperata cylindrica in the United States based on pertinent environmental factors. Through further analysis of the results, they made some relevant suggestions on the prevention and control of this particular species (Ervin and Holly, 2011). Goncalves et al. (2014) showed that the climatic niche is conserved across continents for the expansion of Lantana camara. Based on a large amount of previous evidence (Holm, 1969; Ervin and Holly, 2011; Goncalves et al., 2014; Ray and Quader, 2014; Wan et al., 2019), we now know that environmental changes affect weed expansion, particularly for these 10 species. Therefore, it is necessary to explore the contribution of environmental factors toward the global distribution of these weed species; this will help us realize more effective methods for their prevention and control.

Here we discuss the following two scientific aspects: 1) which environmental factors could affect the distribution of the 10 most dangerous weed species globally, and 2) how could different environmental factors affect weed distribution. To address these questions, we used SDM to model the global distribution of these weed species. Then, the jackknife estimation was used to assess the contribution of environmental factors toward global weed distribution. Finally, we quantified the changing trends in weed distribution based on the relationship between the distribution probability and environmental factors.

\section{Materials and methods}

\section{Species data}

The following 10 weed species are termed as the most dangerous, as per Holm's study (1969): Cynodon dactylon, Cyperus rotundus, Echinochloa colona, Echinochloa crus-galli, Eichhornia crassipes, Eleusine indica, Imperata cylindrica, Lantana camara, Panicum maximum, and Sorghum halepense. These 10 species are dangerous weeds nowadays (Chandramohan and Charudattan, 2001; Punia et al., 2004; Vila-Aiub et al., 2007; Chauhan and Johnson, 2010; Ervin and Holly, 2011; Patel, 2012; Goncalves et al., 2014; Palma-Ordaz and Delgadillo-Rodríguez, 2014). The global occurrence records of these species were downloaded from the Global Biodiversity Information Facility (GBIF; https://www.gbif.org/; assessed on 19 ${ }^{\text {th }}$ March, 2019). The cleaning facilities of ModestR were used to minimize the frequently appearing errors in GBIF (GarcíaRoselló et al., 2014). Duplicate occurrence records were removed on a 10.0 arc-minutes $(\sim 16.0 \mathrm{~km})$ spatial resolution grid. The number of occurrence records ranged from 1795 to 7931 to support the good performance of SDM in our study.

\section{Environmental data}

The environmental data of our study included four climatic factors [annual mean temperature $\left({ }^{\circ} \mathrm{C}^{*} 10\right)$; temperature seasonality (standard deviation*100); annual precipitation $(\mathrm{mm})$; and precipitation seasonality], eight soil factors [bulk density $\left(\mathrm{kg} / \mathrm{m}^{3}\right)$; cation exchange capacity $(\mathrm{cmolc} / \mathrm{kg})$; soil texture fraction clay $(\%)$; coarse fragments volumetric (\%); soil organic carbon stock (tonnes per ha); soil $\mathrm{pH}$; soil texture fraction silt (\%); and soil texture fraction sand (\%)] (Hengl et al., 2014), and one 
human ecological footprint (Sanderson et al., 2002). Non-standard units of temperature were used because this allows for much reduced file sizes, which is important as, for many, downloading large files remains difficult (https://www.worldclim.org). Climate data of 10.0 arc-minutes was downloaded from the WorldClim database (averaged from 1950 to 2000; https://www.worldclim.org), and soil data of 0.5 arc-minutes was downloaded from SoilGrids (https://www.soilgrids.org). The human ecological footprint data was detailed in the study of Sanderson et al. (2002). We chose these environmental factors because they can potentially have a large effect on the distribution of weed species (Holm, 1969; Chicoine et al., 1986; Ervin and Holly, 2011; Goncalves et al., 2014). The four climatic factors, mean and standard deviation temperature and precipitation, were selected because they are widely used in SDMs based on previous studies (Ervin and Holly, 2011; Goncalves et al., 2014; Qin et al., 2014; Wan et al., 2016; Wan and Wang, 2019). Hageer et al. (2017) showed that the eight selected soil factors should be applied to predict distributions of plant species at large spatial scales. The human ecological footprint could explain the the global distribution of plant invaders (Beans et al., 2012; Gallardo et al., 2015). We used ArcGIS 10.6 (https://www.esri.com/software/arcgis/arcgis-for-desktop) to resample the resolution of the soil and human ecological footprint data from 0.5 arc-minutes to 10.0 arc-minutes. Hence, the value ranges of soil and human ecological footprint data were different from the previous studies (i.e., Sanderson et al., 2002; Hengl et al., 2014).

\section{Species distribution modelling and jackknife estimation}

We used Maxent modelling to project the global distribution of these weed species based on species data and environmental factors (Phillips et al., 2017). The Maxent modelling sets were as follows: 1) the regularization multiplier (beta) was kept at 2.0 to produce a smooth and general response shape, which represented a biologically realistic behaviour (Radosavljevic and Anderson, 2014); 2) the maximum number of background points was set to 10,000 , while maintaining the same bias as the buffer of occurrence records of species on a global scale (Phillips et al., 2017); 3) a four-fold cross-validation approach was used $(75 \%$ and $25 \%$ of occurrence records for training and testing modellings, respectively, in each run) to remove bias with respect to occurrence records (Merow et al., 2013); 4) a complementary log-log (cloglog) transformation was applied for the output of Maxent modelling (Phillips et al., 2017); and 5) the other sets were the same as the study of Merow et al. (2013). The cloglog output format gave each grid cell a value between 0.0 and 1.0 , with 0.0 representing the lowest distribution probability of weed species and 1.0 the highest (Phillips et al., 2017). We evaluated the predictive precision of the species distribution models by using the area under the curve (AUC) of the receiver operating characteristic, treating each value of the prediction result as a possible threshold and then obtaining the corresponding sensitivity and specificity values to calculate the curve. Here, the modelling performance was satisfactory for these weed species because the AUC was over 0.7 (Merow et al., 2013).

A jackknife approach was used to assess the percentage contribution (PC) of environmental factors to the distribution probability of weed species using Maxent modelling (Merow et al., 2013; Shcheglovitova and Anderson, 2013; Oke and Thompson, 2015). The output of the jackknife estimation gave each environmental factor a value between $0.0 \%$ and $100.0 \%$, representing the increasing PC of environmental factors to the distribution probability (Shcheglovitova and Anderson, 2013; Oke and Thompson, 2015). Response curves of the environmental factors to the 
distribution probability could be quantified using Maxent modelling (Shcheglovitova and Anderson, 2013). We summed up the values of PC based on the groups of climatic and soil factors. In our study, the contribution of environmental factors toward the species distribution was high when the PC was at least $15.00 \%$ of the modelling for each weed species (Oke and Thompson, 2015).

\section{Results}

\section{Distribution of weed species}

The 10 most dangerous weed species were distributed primarily in Europe, Southeast Asia, Australia, southern regions of North America, central and eastern regions of South America, and central and southern regions of Africa (Fig. 1). Specifically, C. dactylon, C. rotundus, and E. colona cover most regions of Australia (Fig. 1). Compared to other species, E. crus-galli and S. halepense cover only small areas in the central and southern regions of Africa (Fig. 1).

(a) Cynodon dactylon

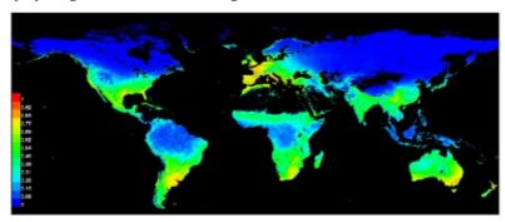

(c) Echinochloa colona

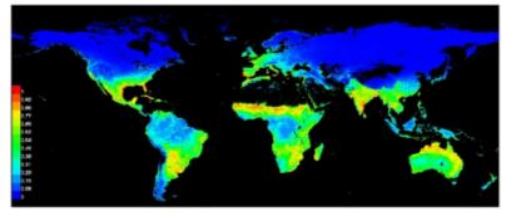

(e) Eichhornia crassipes

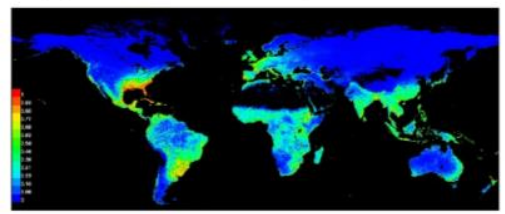

(g) Imperata cylindrica

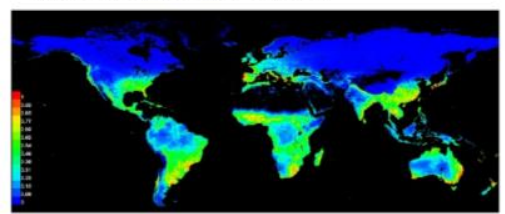

(i) Panicum maximum

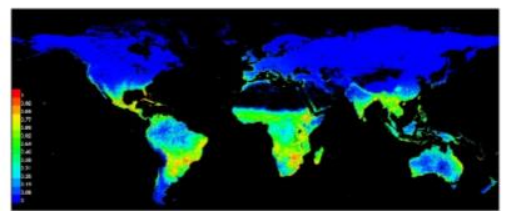

(b) Cyperus rotundus

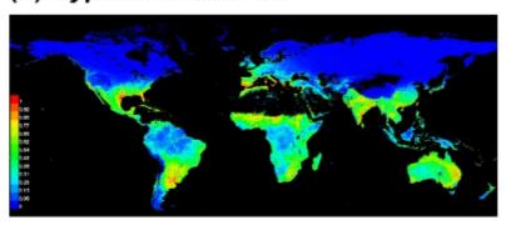

(d) Echinochloa crus-galli

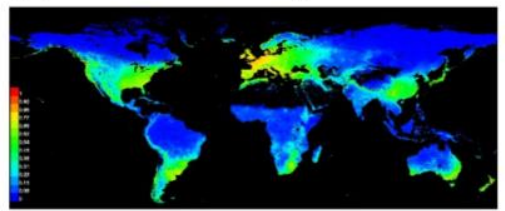

(f) Eleusine indica

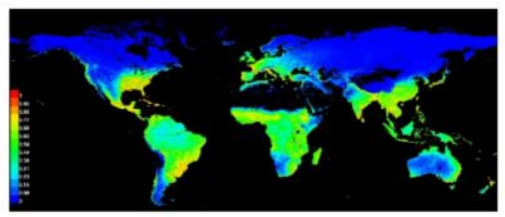

(h) Lantana camara

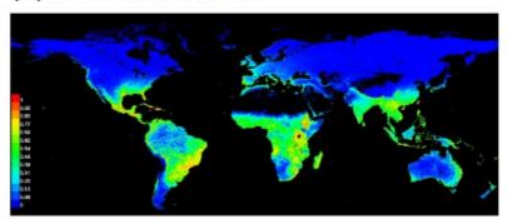

(j) Sorghum halepense

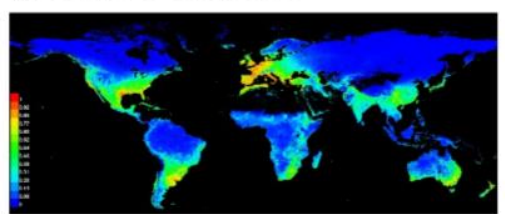

Figure 1. The distribution of 10 most dangerous weed species on a global scale. The colour of maps from blue to red represents the distribution probability of the 10 most dangerous weed species from low to high levels 


\section{Contribution of environmental factors to weed distribution}

PCs for all climatic factors were over $50 \%$ across all these species, thus indicating that the climatic factor made the largest contribution toward the global distribution (Table 1). Among the climatic factors, annual mean temperature made the largest contribution toward the distribution, except for $S$. halepense. Further, temperature seasonality and annual precipitation played an important role in the distribution of seven weed species, i.e., C. dactylon, E. colona, E. crus-galli, E. crassipes, E. indica, P. maximum, and $S$. halepense (PC over 15.00\%; Table 1). Although the distribution ranges were similar among the species, temperature and precipitation made different contributions toward the distribution, and the response curves of the climatic factors to the distribution varied among different weed species (Fig. 2). The response curves of climatic factors to the distribution were simply unimodal for E. crus-galli, E. crassipes, L. camara, P. maximum, and S. halepense. Also, an obvious increasing trend was observed in the unimodal changes for $C$. dactylon, C. rotundus, E. colona, E. indica, and I. cylindrica (Fig. 2). We found that soil factors made a small contribution toward the global distribution (Table 1). At large spatial scales, climatic factors made a larger contribution toward weed distribution than soil factors (Table 1). PC was higher than $15.00 \%$ for the human ecological footprint for the global distribution of E. crus-galli, E. crassipes, E. indica, L. camara, and S. halepense (Table 1). Furthermore, the distribution probability enhanced with an increased human ecological footprint (Fig. 3).

\section{Discussion}

We found that the distribution range of the 10 most dangerous weed species included Europe, Southeast Asia, Australia, southern regions of North America, central and eastern regions of South America, and central and southern regions of Africa, indicating that these weed species have great potential to expand widely around the world. Hence, as per Holm (1969), the threat that these species pose to the ecosystem and biodiversity should be a global issue. It is therefore important to explore the drivers behind the wide distribution of these weeds so that the effectiveness of the preventive and control methods can be improved (Panetta, 2015; Bajwa et al., 2016; Wan and Wang, 2019).

\section{Contribution of climatic factors to weed distribution}

We found that PCs for all climatic factors were over 50\% across all these species, thus indicating that the climatic factor made the largest contribution toward the global distribution (Table 1). Among the climatic factors, annual mean temperature made the largest contribution toward the distribution, except for S. halepense (PC over 15.00\%; Table 1). Although the distribution ranges were similar among the species, temperature and precipitation made different contributions toward the distribution, and the response curves of the climatic factors to the weed distribution varied among different weed species (Fig. 2). These results indicated that suitable climatic conditions could drive the global expansion of weed species. Previous studies (e.g., Holm, 1969; Tilman et al., 2006; Shimono and Konuma, 2008; Ervin and Holly, 2011; Panetta, 2015; Wan et al., 2017; Zhang et al., 2018) have shown that weeds can strongly adapt to rapid environmental changes and could grow exponentially in the near future. Weeds have a high level of phenotypic plasticity, and are capable of relatively rapid genetic change to enhance their ability to invade new areas in response to climate change (Clements and 
Ditommaso, 2011). Hence, it is important to understand the changing trends in weed distribution along with the variation in global climate changes (Ervin and Holly, 2011; Wan et al., 2016; Zhang et al., 2018; Wang et al., 2019). Figure 2 shows us the importance of monitoring weed expansion under different climatic conditions.

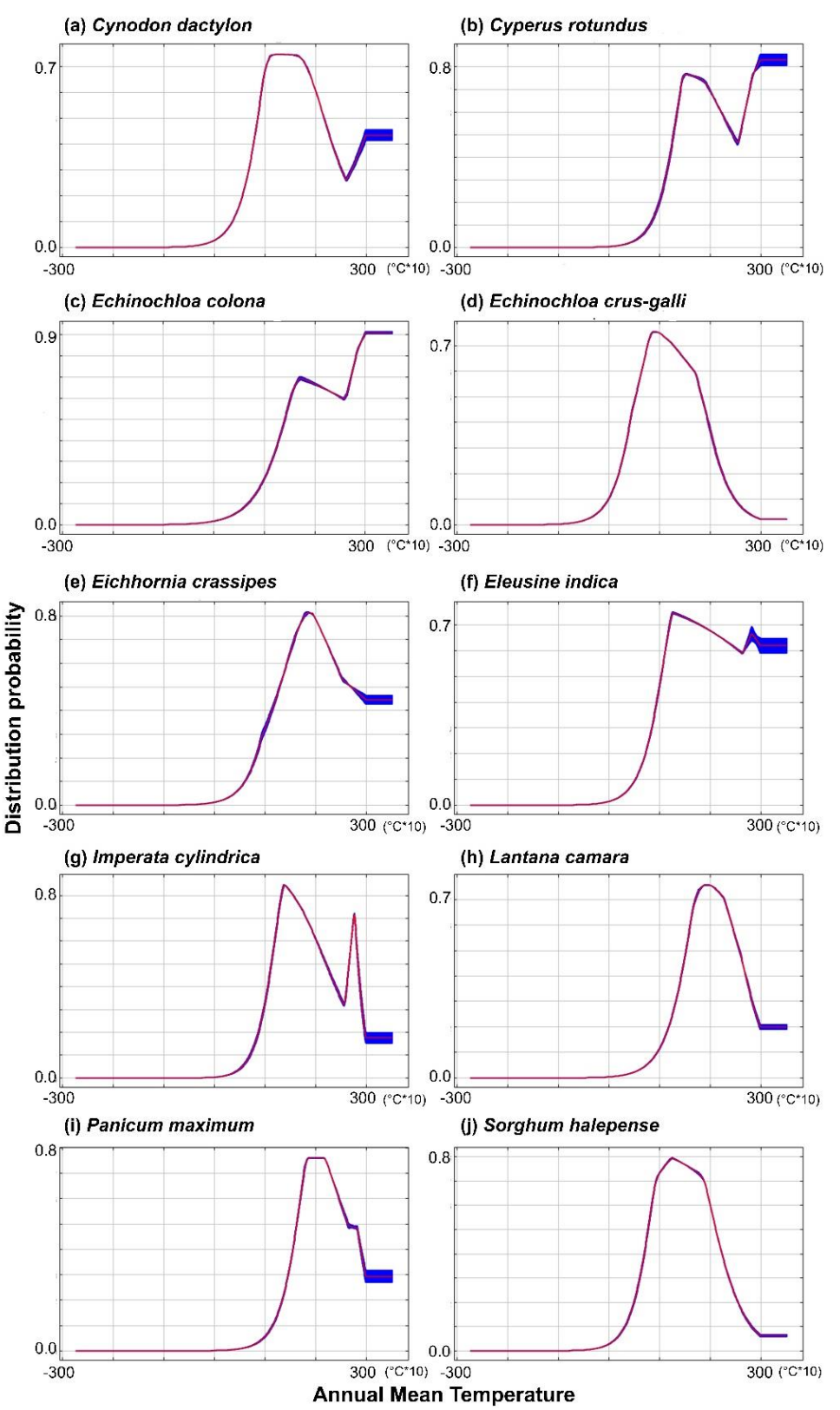

Figure 2. Response curves of annual mean temperature to weed distribution on a global scale

\section{Contribution of soil factors toward weed distribution}

Our results showed that soil factors made a negligible contribution toward global distribution (PC less than 15.00\%; Table 1), thus indicating that soil factors solely could not drive weed expansion on a global scale. Numerous experimental studies (Tilman et al., 2006; Ramakrishna et al., 2006; Welch et al., 2016; Zhang et al., 2018) have shown that small-scale soil conditions play an important role in the spatial distribution of weed 
species. However, based on our results, climatic factors made a larger contribution toward weed distribution than soil factors at large spatial scales. At small spatial scales, biotic factors (e.g., soil microorganisms) make a large contribution to weed physiology and weed seed banks (Kremer, 1993; Kennedy et al., 1999). Attention was paid to abiotic factors in our study. This difference may have been due to the effects of the spatial scale on the relationship between soil factors and weed distribution (Ervin and Holly, 2011; Goncalves et al., 2014). However, we should still pay attention to the effects of soil factors because a weed monitoring strategy should be based on different spatial scales, from something as large as a continent to as small as a micro-habitat (Buhler et al., 1997; Dekker et al., 1999; Gallandt, 1999; Wallace et al., 2018).

\section{Contribution of human ecological footprint toward weed distribution}

The human ecological footprint made a large contribution toward the global distribution of E. crus-galli, E. crassipes, E. indica, L. camara, and S. halepense (PC higher than $15.00 \%$; Table 1). Furthermore, the distribution probability enhanced with an increased human ecological footprint (Fig. 3). The human ecological footprint is a good indicator of human influence in that it estimates the quantity of nature necessary to support the consumption habits of one individual, population, product, activity, or service (Sanderson et al., 2002; Wan et al., 2018). Our results provide clear evidence that human influence could drive the expansion of the above-mentioned 5 species on a global scale, although previous studies (e.g., Young and Evans, 1976; Treier and Müller-Schärer, 2011; Alvarado-Serrano et al., 2019; Krak et al., 2019) have shown that weeds could expand in lands degraded by human influence. Such influences of the human ecological footprint include global trade and transportation (Sanderson et al., 2002; Wiedmann and Lenzen, 2018). Therefore, we should consider making provisions for better control of global trade and transportation if we are to restrict the global distribution of these five species (Holm, 1969; Panetta, 2015; Zhang et al., 2018).
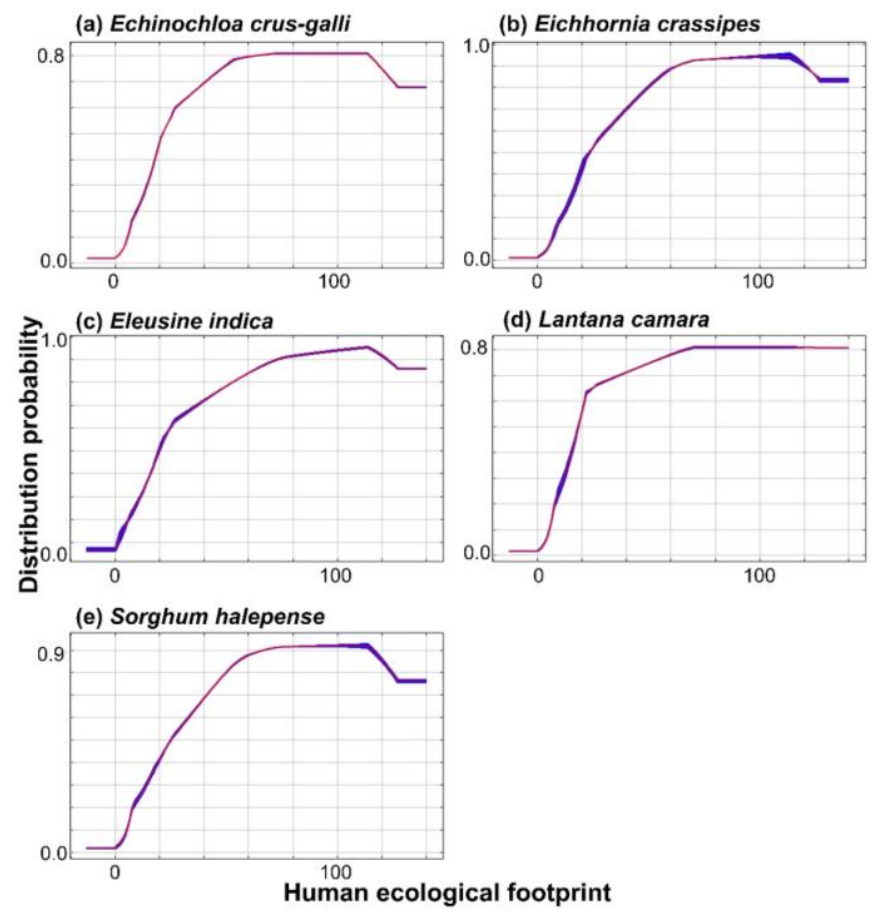

Figure 3. Response curves of human ecological footprint to weed distribution on a global scale 
Table 1. Contribution of environmental factors toward the distribution of 10 most dangerous weed species on a global scale

\begin{tabular}{|c|c|c|c|c|c|c|c|c|c|c|c|c|c|c|c|}
\hline Species & Bio1 & Bio4 & Bio12 & Bio15 & BLD & CEC & CLYPPT & CRFVOL & ORCDRC & PHIHOX & SLTPPT & SNDPPT & Climate & Soil & HF \\
\hline $\begin{array}{l}\text { Cynodon } \\
\text { dactylon }\end{array}$ & 44.30 & 43.94 & 1.08 & 2.90 & 0.43 & 0.03 & 0.00 & 0.04 & 0.00 & 2.14 & 0.14 & 0.06 & 92.22 & 2.86 & 4.93 \\
\hline $\begin{array}{l}\text { Cyperus } \\
\text { rotundus }\end{array}$ & 68.17 & 14.30 & 1.89 & 1.94 & 0.79 & 0.10 & 0.81 & 0.14 & 0.00 & 2.32 & 1.00 & 0.66 & 86.30 & 5.82 & 7.88 \\
\hline $\begin{array}{c}\text { Echinochloa } \\
\text { colona }\end{array}$ & 62.00 & 24.92 & 2.62 & 0.93 & 1.20 & 0.58 & 0.23 & 0.07 & 0.05 & 4.14 & 0.60 & 0.08 & 90.47 & 6.94 & 2.59 \\
\hline $\begin{array}{c}\text { Echinochloa } \\
\text { crus-galli }\end{array}$ & 21.01 & 20.00 & 1.79 & 14.15 & 0.08 & 0.08 & 0.17 & 0.10 & 0.02 & 0.15 & 0.12 & 0.04 & 56.94 & 0.75 & 42.31 \\
\hline $\begin{array}{l}\text { Eichhornia } \\
\text { crassipes }\end{array}$ & 30.17 & 6.09 & 15.13 & 3.16 & 0.80 & 1.59 & 0.95 & 2.85 & 0.00 & 2.30 & 2.12 & 0.34 & 54.55 & 10.95 & 34.50 \\
\hline $\begin{array}{l}\text { Eleusine } \\
\text { indica }\end{array}$ & 46.77 & 3.26 & 25.21 & 0.67 & 0.49 & 0.45 & 1.03 & 0.34 & 0.03 & 2.36 & 0.09 & 0.12 & 75.91 & 4.92 & 19.17 \\
\hline $\begin{array}{l}\text { Imperata } \\
\text { cylindrica }\end{array}$ & 64.08 & 10.31 & 13.42 & 3.48 & 0.61 & 0.17 & 0.04 & 2.02 & 0.01 & 1.23 & 0.08 & 1.50 & 91.29 & 5.65 & 3.06 \\
\hline $\begin{array}{l}\text { Lantana } \\
\text { camara }\end{array}$ & 50.71 & 11.86 & 11.88 & 0.80 & 0.68 & 0.36 & 0.73 & 0.16 & 0.04 & 1.26 & 0.94 & 0.50 & 75.25 & 4.66 & 20.09 \\
\hline $\begin{array}{l}\text { Panicum } \\
\text { maximum }\end{array}$ & 56.35 & 24.40 & 2.57 & 2.47 & 0.05 & 0.68 & 0.58 & 0.01 & 0.07 & 3.18 & 0.39 & 0.37 & 85.78 & 5.33 & 8.89 \\
\hline $\begin{array}{l}\text { Sorghum } \\
\text { halepense }\end{array}$ & 23.69 & 31.78 & 0.55 & 3.86 & 1.18 & 1.01 & 0.18 & 0.16 & 0.03 & 1.22 & 1.61 & 0.03 & 59.88 & 5.43 & 34.69 \\
\hline
\end{tabular}

Climate, soil, and HF denote the total contribution of climate, soil, and human ecological footprint toward weed distribution. The bold values denote the large contribution of environmental variables toward weed distribution. The environmental codes were following: Bio1: annual mean temperature ( $\left.{ }^{\circ} \mathrm{C}^{*} 10\right)$; Bio4: temperature seasonality (standard deviation*100); Bio12: annual precipitation (mm); Bio15: precipitation seasonality (coefficient of variation); BLD: bulk density (kg/cubic meter); CEC: cation exchange capacity (cmolc/kg); CLYPPT: soil texture fraction clay (\%); CRFVOL: coarse fragments volumetric (\%); ORCDRC: soil organic carbon stock (tonnes per ha); PHIHOX: soil pH; SLTPPT: soil texture fraction silt (\%); SNDPPT: soil texture fraction sand (\%) 


\section{Conclusions}

We conclude that climatic factors coupled with the human ecological footprint made a significant contribution toward the distribution of the 10 most dangerous weed species globally. The contribution of the annual mean temperature was the largest for all the species, except for $S$. halepense. Various weed species respond differently to the annual mean temperature, but the human ecological footprint could enhance global expansion. Hence, we should analyze climate change and human influence together for the global prevention and control of these 10 most dangerous weed species. The spatial pattern of climates and the human ecological footprint should be closely monitored in Europe, Southeast Asia, Australia, southern regions of North America, central and eastern regions of South America, and central and southern regions of Africa. Future studies should attach importance to the contribution of environmental factors towards more weed species at the global scale. Weed control and management is increasingly becoming a global issue due to global human activities (e.g., global transportation and trade; Beans et al., 2012; Gallardo et al., 2015; Alvarado-Serrano et al., 2019). More and more weed species have a high potential to expand around the world. Furthermore, future studies also should pay attention to the importance of biotic factors (e.g., soil microorganisms) to the distribution of weed species globally. Therefore, studies on more weed species and biotic factors should be conducted for weed species worldwide.

Acknowledgements. Many thanks are due to the editor and two reviewers for their useful and constructive comments, which helped improve an earlier version of our manuscript. This work was supported by the National Natural Science Foundation of China (NSFC; 31800464 and 31800449), and the Basic Research Project of Qinghai Province, China (2019-ZJ-960Q).

\section{REFERENCES}

[1] Alvarado-Serrano, D. F., Van Etten, M. L., Chang, S. M., Baucom, R. S. (2019): The relative contribution of natural landscapes and human-mediated factors on the connectivity of a noxious invasive weed. - Heredity 122: 29.

[2] Bajwa, A. A., Chauhan, B. S., Farooq, M., Shabbir, A., Adkins, S. W. (2016): What do we really know about alien plant invasion? A review of the invasion mechanism of one of the world's most dangerous weeds. - Planta 244: 39-57.

[3] Beans, C. M., Kilkenny, F. F., Galloway, L. F. (2012): Climate suitability and human influences combined explain the range expansion of an invasive horticultural plant. Biological Invasions 14: 2067-2078.

[4] Buhler, D. D., Hartzler, R. G., Forcella, F. (1997): Implications of weed seedbank dynamics to weed management. - Weed Science 45: 329-336.

[5] Chandramohan, S., Charudattan, R. (2001): Control of seven grasses with a mixture of three fungal pathogens with restricted host ranges. - Biological Control 22: 246-255.

[6] Chauhan, B. S., Johnson, D. E. (2010): Implications of narrow crop row spacing and delayed Echinochloa colona and Echinochloa crus-galli emergence for weed growth and crop yield loss in aerobic rice. - Field Crops Research 117: 177-182.

[7] Chicoine, T. K., Fay, P. K., Nielsen, G. A. (1986): Predicting weed migration from soil and climate maps. - Weed Science 34: 57-61.

[8] Clements, D. R., Ditommaso, A. (2011): Climate change and weed adaptation: can evolution of invasive plants lead to greater range expansion than forecasted? - Weed Research 51: 227-240. 
[9] Dekker, J. (1999): Soil weed seed banks and weed management. - Journal of Crop Production 2: 139-166.

[10] Ervin, G. N., Holly, D. C. (2011): Examining local transferability of predictive species distribution models for invasive plants: an example with cogongrass (Imperata cylindrica). - Invasive Plant Science and Management 4: 390-401.

[11] Gallandt, E. R., Liebman, M., Huggins, D. R. (1999): Improving soil quality: implications for weed management. - Journal of Crop Production 2: 95-121.

[12] Gallardo, B., Zieritz, A., Aldridge, D. C. (2015): The importance of the human footprint in shaping the global distribution of terrestrial, freshwater and marine invaders. - PloS One 10: e0125801.

[13] García-Roselló, E., Guisande, C., Heine, J., Pelayo-Villamil, P., Manjarrés-Hernández, A., González Vilas, L., González-Dacosta, J., Vaamonde, A., Granado-Lorencio, C. (2014): Using ModestR to download, import and clean species distribution records. Methods in Ecology and Evolution 5: 708-713.

[14] Goncalves, E., Herrera, I., Duarte, M., Bustamante, R. O., Lampo, M., Velasquez, G., Sharma, G. P., García-Rangel, S. (2014): Global invasion of Lantana camara: has the climatic niche been conserved across continents?. - PLoS One 9: e111468.

[15] Hageer, Y., Esperón-Rodríguez, M., Baumgartner, J. B., Beaumont, L. J. (2017): Climate, soil or both? Which variables are better predictors of the distributions of Australian shrub species? - PeerJ 5: e3446.

[16] Hengl, T., de Jesus, J. M., MacMillan, R. A., Batjes, N. H., Heuvelink, G. B., Ribeiro, E., Samuel-Rosa, A., Kempen, B., Leenaars, J. G. B., Walsh, M. G., Gonzalez, M. R. (2014): SoilGrids $1 \mathrm{~km}$-global soil information based on automated mapping. - PloS One 9: e105992.

[17] Holm, L. (1969): Weeds problems in developing countries. - Weed Science 17: 113-118.

[18] Kennedy, A. C. (1999): Soil microorganisms for weed management. - Journal of Crop Production 2: 123-138.

[19] Krak, K., Habibi, F., Douda, J., Vít, P., Lomonosova, M. N., Wang, L., Mandák, B. (2019): Human-mediated dispersal of weed species during the Holocene: a case study of Chenopodium album agg. - Journal of Biogeography 46: 1007-1019.

[20] Kremer, R. J. (1993): Management of weed seed banks with microorganisms. Ecological Applications 3: 42-52.

[21] Merow, C., Smith, M. J., Silander Jr, J. A. (2013): A practical guide to MaxEnt for modeling species' distributions: what it does, and why inputs and settings matter. Ecography 36: 1058-1069.

[22] Oke, O. A., Thompson, K. A. (2015): Distribution models for mountain plant species: the value of elevation. - Ecological Modelling 301: 72-77.

[23] Palma-Ordaz, S., Delgadillo-Rodríguez, J. (2014): Distribución potencial de ocho especies exóticas de carácter invasor en el estado de Baja California, México. - Botanical Sciences 92: 587-597.

[24] Panetta, F. D. (2015): Weed eradication feasibility: lessons of the 21st century. - Weed Research 55: 226-238.

[25] Patel, S. (2012): Threats, management and envisaged utilizations of aquatic weed Eichhornia crassipes: an overview. - Reviews in Environmental Science and Bio/Technology 11: 249-259.

[26] Phillips, S. J., Anderson, R. P., Dudík, M., Schapire, R. E., Blair, M. E. (2017): Opening the black box: an open-source release of Maxent. - Ecography 40: 887-893.

[27] Punia, S. S., Malik, R. S., Yadav, A., Rinwa, R. S. (2004): Effect of varying density of Cyperus rotundus, Echinochloa colona and Trianthema portulacastrum on mungbean. Indian Journal of Weed Science 36: 280-281.

[28] Qin, Z., DiTommaso, A., Wu, R. S., Huang, H. Y. (2014): Potential distribution of two A mbrosia species in $\mathrm{C}$ hina under projected climate change. - Weed Research 54: 520-531. 
[29] Radosavljevic, A., Anderson, R. P. (2014): Making better Maxent models of species distributions: complexity, overfitting and evaluation. - Journal of Biogeography 41: 629643.

[30] Ramakrishna, A., Tam, H. M., Wani, S. P., Long, T. D. (2006): Effect of mulch on soil temperature, moisture, weed infestation and yield of groundnut in northern Vietnam. Field Crops Research 95: 115-125.

[31] Ray, A., Quader, S. (2014): Genetic diversity and population structure of Lantana camara in India indicates multiple introductions and gene flow. - Plant Biology 16: 651-658.

[32] Sanderson, E. W., Jaiteh, M., Levy, M. A., Redford, K. H., Wannebo, A. V., Woolmer, G. (2002): The human footprint and the last of the wild: the human footprint is a global map of human influence on the land surface, which suggests that human beings are stewards of nature, whether we like it or not. - BioScience 52: 891-904.

[33] Shcheglovitova, M., Anderson, R. P. (2013): Estimating optimal complexity for ecological niche models: a jackknife approach for species with small sample sizes. Ecological Modelling 269: 9-17.

[34] Shimono, Y., Konuma, A. (2008): Effects of human-mediated processes on weed species composition in internationally traded grain commodities. - Weed Research 48: 10-18.

[35] Tilman, D., Reich, P. B., Knops, J. M. H. (2006): Biodiversity and ecosystem stability in a decade-long grassland experiment. - Nature 441: 629.

[36] Treier, U. A., Müller-Schärer, H. (2011): Differential effects of historical migration, glaciations and human impact on the genetic structure and diversity of the mountain pasture weed Veratrum album L. - Journal of Biogeography 38: 1776-1791.

[37] Vila-Aiub, M. M., Balbi, M. C., Gundel, P. E., Ghersa, C. M., Powles, S. B. (2007): Evolution of glyphosate-resistant johnsongrass (Sorghum halepense) in glyphosateresistant soybean. - Weed Science 55: 566-571.

[38] Wallace, J. M., Keene, C. L., Curran, W., Mirsky, S., Ryan, M. R., VanGessel, M. J. (2018): Integrated weed management strategies in cover crop-based, organic rotational no-till corn and soybean in the mid-Atlantic region. - Weed Science 66: 94-108.

[39] Wang, C. J., Yin, G. J., Song, Z. M., Wan, J. Z. (2019): Evaluating the spread of 10 invasive weeds in Chinese nature reserves under climate change scenarios in consideration of different scales. - Applied Ecology and Environmental Research 17: 3513-3533.

[40] Wan, J. Z., Wang, C. J. (2019): Determining key monitoring areas for the 10 most important weed species under a changing climate. - Science of the Total Environment 683: 568-577.

[41] Wan, J. Z., Wang, C. J., Yu, F. H. (2016): Risk hotspots for terrestrial plant invaders under climate change at the global scale. - Environmental Earth Sciences 75: 1012.

[42] Wan, J. Z., Wang, C. J., Tan, J. F., Yu, F. H. (2017): Climatic niche divergence and habitat suitability of eight alien invasive weeds in China under climate change. - Ecology and Evolution 7: 1541-1552.

[43] Wan, J. Z., Wang, C. J., Yu, F. H. (2018): Human footprint and climate disappearance in vulnerable ecoregions of protected areas. - Global and Planetary Change 170: 260-268.

[44] Wan, J. Z., Wang, C. J., Yu, F. H. (2019): Large-scale environmental niche variation between clonal and non-clonal plant species: roles of clonal growth organs and ecoregions. - Science of the Total Environment 652: 1071-1076.

[45] Welch, R. Y., Behnke, G. D., Davis, A. S., Masiunas, J., Villamil, M. B. (2016): Using cover crops in headlands of organic grain farms: effects on soil properties, weeds and crop yields. - Agriculture, Ecosystems \& Environment 216: 322-332.

[46] Wiedmann, T., Lenzen, M. (2018): Environmental and social footprints of international trade. - Nature Geoscience 11: 314-321.

[47] Young, J. A., Evans, R. A. (1976): Responses of weed populations to human manipulations of the natural environment. - Weed Science 24: 186-190. 
[48] Zhang, Y., Wang, L., Yuan, Y., Xu, J., Tu, C., Fisk, C., Zhang, W. J., Chen, X., Ritchie, D., Hu, S. (2018): Irrigation and weed control alter soil microbiology and nutrient availability in North Carolina Sandhill peach orchards. - Science of the Total Environment 615: 517-525. 